\title{
THE DOCTRINE OF OCCUPATION AND THE FOUNDING OF AUSTRALIA
}

\author{
Jan Rudnicki*
}

\section{ABSTRACT}

There is certainly nothing surprising in the thesis that many legal doctrines, however complex or sophisticated they could be, are quite often difficult to apply directly. This problem occurs both in domestic and in international law. Traditionally considered modes of acquiring the territory of a state, mostly derived by modern scholars from Roman private law, make for a good example of this problem. It rarely happens that any of them provides a complete answer to the question of how a state acquired its legal title to a certain portion of land, especially when the title is contested. Scholars tend to emphasise that the modes of acquisition typified in textbooks of international law do not exactly reflect the complex process that occurs when a tribunal or an arbitrator has to adjudicate between competing claims. Yet, particularly where no dispute occurs, there are certain situations when some of the modes of acquiring state territory appear in pure form. Such is the case of Australia and the creation of a legal title to the vast territory of this continent by Great Britain. The goal of this paper is therefore to look at the beginnings of Australia through the prism of the doctrine of occupation, which has found direct application in this case.

Keywords: Occupation; international law; Roman law; Australia; Vattel; territory

* Assistant Professor, Chair: Group of European Legal Tradition, Faculty of Law and Administration, University of Warsaw. 


\section{The beginnings of the doctrine of occupation}

The birth and early development of modern international law was catalysed by a series of events we know today as the age of discovery. As a Spanish author highlights, describing the problems that his ancestors were faced with,

Europeans saw themselves confronted with the problem of the law of colonization, and from this point of view it finally became necessary to pose the problem of the law of nations in global perspective. The impact of the discovery of America on the law of nations thus appears as a particular effect of the impact which the Discovery had in the more general domain of human culture and knowledge. ${ }^{1}$

The legal theory of feudal Europe, based on the pillars of Roman and canon law, failed to manage these new problems. Lesaffer found "the feudal and local customary laws that formed the basis of territorial divisions within the Latin West inappropriate. There were no feudal or customary titles for the new territories which could substantiate the claim of one prince vis-à-vis his European counterparts, while the feudal and local law systems were completely irrelevant to native peoples. The authority of the Pope to dispose of the non-Christian lands, which had its foundations in some precepts taken from medieval canon law, was equally unsatisfactory". ${ }^{2}$ Setting aside the interesting, but having no direct reference to the topic of this paper, problem of papal donations and bulls, we shall move to answers that were given to the above described problems by scholars known today as the "fathers of international law". The renowned Spaniard Francisco de Vitoria, in his work De Indis, was probably the first to propose that "regions which are deserted become, by the law of nations and the natural law, the property of the first occupant". ${ }^{3}$ This idea obviously did not appear out of nowhere. Vitoria, as a true scholastic should do, points the source by direct reference to Justinian's Institutiones. ${ }^{4}$ The ancient Roman rule that "what does not belong to anyone by natural law becomes the property of the person who first acquires it," ${ }^{5}$ remains largely unchanged in civilian private law jurisdictions until today, ${ }^{6}$ and it was perfectly known to Vitoria, a theological and legal scholar of the University of Salamanca. He emphasises that the rule can be derived from both the

1 Truyol y Sera 1971: 309.

2 Lesaffer 2005: 41.

3 See Francisco de Vitoria De Indis 2 7: Et videtur quod hic titulus sit idoneus, quia illa, quae sunt deserta, fiunt iure gentium et naturali occupantis [...] Ius autem gentium est, ut quod in nullius bonis est, occupant conceditur (English translation in the main text by JB Scott (New York London (1964)).

$4 \quad$ Vitoria twice refers directly to Inst de rerum divisione, § ferae bestiae (see I 2112 ).

5 See Digest 4113 pr: Gaius libro secundo rerum cottidianarum sive aureorum: Quod enim nullius est, id ratione naturali occupanti conceditur. In almost the same words in I 2112 (English translation in the main text by Scott The Civil Law (1932)).

6 In modern civil codes occupation as a mode of acquiring ownership is applicable to movable objects only. See, eg, sec 958(1) of the German Civil Code or art 181 of the Polish Civil Code. 
ius naturale and the ius gentium and is therefore universally applicable. Other famous authors of the formative period of international law, including Grotius, followed Vitoria's path. They - as Lesaffer aptly summarises - took the Roman concept of occupation and stripped it of its particulars and technicalities of private law, creating a pure legal concept applicable in international relations. ${ }^{7}$ Moving away from the main topic we can observe that such a manner of creation of rules, doctrines and principles of international law was quite common. From the perspective of three centuries it allowed TE Holland to state, perhaps with slight exaggeration, that "the Law of Nations is but private law writ large". 8

Thus, the main idea of occupation was simple but, as usual, the devil is in the detail. At least two crucial questions arise: First, what does it exactly mean to occupy land? Second, what qualities must a territory display to be considered terra nullius? In civil law both answers are rather intuitive. Occupation, since Roman times, materialises simply by taking into possession a thing that has never had any owner or had been abandoned by the previous owner (res nullius). However, when it comes to territorial acquisitions by monarchs, states or nations, it is not so obvious what shall be regarded as "taking into possession" and - what is probably a more complex issue - it is easy to observe that hardly any newly discovered lands were completely uninhabited. Nowadays, basic answers to these questions may be found in every textbook of international law, and it is worth knowing that the process of their formation by the practice of states and theories of legal scholars took several hundred years. Both issues will be discussed hereafter with direct references to the case of colonisation of Australia.

\section{Symbolic or effective occupation?}

It must be stated at the outset of this section that contrary to the common opinion the mere fact of discovery was at no time regarded as capable of granting a fully developed title to territory. ${ }^{9}$ Appropriation by some means has always been regarded as inevitable and so the important question is whether the taking of land into possession should be performed merely by symbolic acts or whether it should immediately be followed by effective occupation. Therefore, mere discovery only creates an inchoate title. ${ }^{10}$ However, a distinction between discovery and taking a newly discovered land into possession by symbolic acts may be regarded as a purely academic one, as the practice of performing many sorts of legal acts on distant, newly discovered shores, used to be very common. It is as old as the great European discoveries themselves, since the Portuguese placed padrões ${ }^{11}$ on the

7 Lesaffer 2005: 45.

8 Holland 1898: 152.

9 Heydte 1935: 451.

10 Oppenheim and Lauterpacht 1958: 558.

11 Wooden or stone crosses, bearing the royal coat of arms of the Kingdom of Portugal and the Algarves. 
Atlantic islands and all along the coasts of Africa and Brazil. Subsequently, Spanish, English and French explorers, equipped with royal privileges and charters entitling them to take every new land into their king's possession, raised their sails. In most cases hoisting a flag, issuing a proclamation or giving a gun salute were the only means available, since the establishment of a colony or another form of effective governance was a complex and expensive operation. Still, it is doubtful if a symbolic act of appropriation sufficed in any case to establish a valid and long-lasting title. Von der Heydte highlights that royal charters usually mentioned both symbolic occupation and effective conquest or establishment of forts, towns or trading posts. ${ }^{12}$ The doctrine of that time was not clear concerning this matter either. A passage from the Tractatus de insulis by the German scholar Johann Gryphiander from 1623 provides a good example, as the author describes a means of acquiring sovereignty rights over no-man's land as inventio, but states that factual possession is the main premise thereof. ${ }^{13}$

The case of Australia turns out to be a gauge of the changing doctrine and practice of international law regarding the issue. The question who the first European was to reach the coasts of this smallest of continents is beyond the scope of this paper. What is, however, of great importance concerning the problem of occupation are the Dutch discoveries. When Abel Tasman set off on his great voyage in 1642, he was empowered by the Dutch East India Company to take possession of new lands. He actually performed many acts of symbolic appropriation on the coasts he explored and during his life such practice was sufficient - at least - to create general recognition for the usage of "New Holland" as the first official name of Australia and "Van Diemen's Land" for the island now known as Tasmania. But the voyage of Tasman or any of his compatriots was not followed by any more definite action by the Republic of the Seven United Provinces, or by the Company. The Dutch were not interested in establishing any settlement or trading post on those lands simply because they did not offer any promising perspectives for trade. So decades passed, and Tasman's symbolic actions remained unsupported by any other measures and the practice of European colonial powers tended to turn towards the principle of effectiveness. Therefore, even if symbolic occupation could be regarded as sufficient to create a title when Tasman was mapping the cost of New Holland, the continuous evolution of both practice and theory changed the situation completely.

This evolution was clearly visible in the jurisprudence in the second half of the eighteenth century. Emerich de Vattel, a Swiss scholar and diplomat in the service of Augustus, King of Poland and Elector of Saxony, was the first to firmly state a principle nowadays considered as obvious. ${ }^{14}$ In his canonic work dating from 1758 he states that

12 Heydte 1935: 454-455.

13 Grewe 2000: 252.

14 Ruddy 1968: 282. 
[a]ll mankind have equal rights to things that have not yet fallen into the possession of any one; and those things belong to the person who first takes possession of them. When, therefore, a nation finds a country uninhabited, and without an owner, it may lawfully take possession of it: and after it has sufficiently made known its will in this respect, it cannot be deprived of it by another nation. Thus navigators going on voyages of discovery, furnished with a commission from their sovereign, and meeting with islands and other lands in a desert state, have taken possession of them in the name of their nation: and this title has been usually respected, provided it was soon after followed by a real possession ... The law of nations will therefore not acknowledge the property and sovereignty of a nation over any uninhabited countries, except those of which it has really taken actual possession, in which it has formed settlements, or of which it makes actual use. In effect, when navigators have met with desert countries in which those of other nations had, in their transient visits, erected some monument to show their having taken possession of them, they have paid as little regard to that empty ceremony, as to the regulation of the popes, who divided a great part of the world between the crowns of Castile and Portugal. ${ }^{15}$

Vattel begins with the general statement on occupation as a rule of natural law, but what makes his text particularly important is the conclusion he derives from the observation of the practice of states. He concludes by stating that title is created only by "a real possession" that is an effective establishment of rule over a territory.

\section{Facts regarding the colonisation of Australia}

Lieutenant James Cook reached Botany Bay twelve years after Vattel had published his Law of Nations, so the doctrine formulated in this work was very timely. On 21 August 1770, Cook hoisted a Union Jack on a small plot of land known now as Possession Island in Queensland and read a proclamation stating that a large portion of New Holland's shore had been taken into possession of King George III. The ceremony was rather modest since all Endeavour's cannons had been thrown overboard to lighten the ship and enable her to sail over barrier reefs. Therefore, only muskets' salvos were fired. ${ }^{16}$ According to the aforementioned theory, this act could be considered only as a symbolic act of appropriation, but Cook's actions had to be followed by actual occupation. After a relatively short period of eighteen years (especially compared to the period of more than 150 years during which no such action had been performed by the Dutch) the First Fleet arrived on 26 January, carrying inmate settlers, soldiers and supplies. Its commander, captain Arthur Phillip, founded the first settlement. The colony was formally established a few days later, yet "accounts differ as to details of the small ceremony that occurred on the 26 January 1788 near the head of Sydney Cove. But in essentials they agree. A flag staff had been erected. From it the Union Jack was displayed. Standing under the flag the Governor and a group of officers drank toasts to the health of the King and the

16 Huges 1987: 55. 
Royal Family and the success of the new Colony. A party of Marines fired a feude joie. All gave three cheers, and the cheering was echoed by the ship's company of the 'Supply' lying at anchor in the Cove. Governor Phillip had entered upon his government". ${ }^{17}$ It is, however, not very likely that Phillip, being an experienced officer of the Royal Navy, had at this very moment any particular legal doctrine in mind. Nor is it likely to prove whether the British government at the time considered the legal issue either, since there is no sign of any legal reasoning in the most important act of law concerning the establishment of New South Wales: Governor Phillip's Instructions of 25 April 1787, already “constituting and appointing [Phillip] to be Our [King's] Captain General and Governor in Chief of Our Territory called New South Wales". ${ }^{18}$ It is therefore rather clear that the doctrine was - as usual - at best in the far background of those events. The practical circumstances were clearly decisive, since the British were well aware of the fact that the French explorer La Perouse has just appeared in Botany Bay. Phillip "knew well enough that the title of the Crown to the new land would depend not so much on doctrines of international law as on effective possession; not only on the raising of the British flag, but also on the existence of the British fleet". ${ }^{19}$

However, the following events enable us to adjust a doctrine to the facts $a$ posteriori. First, the administration of the newly occupied lands was formally established as soon as possible - on 7 February. The process of colonisation of the whole vast land was obviously extended in time, but by the middle of the nineteenth century Great Britain had unquestionably taken effective possession of the whole continent - or at least all hospitable parts of its shores. On no occasion was that met with any reaction from the Dutch who lost interest in Australia almost as soon as Tasman claimed it for their Republic. Therefore, this process carries some importance for the development of international law since it provides a practical example that symbolic annexation was definitely considered not to grant full sovereignty rights over newly found regions, but to create "only an inchoate title which finally perished unless followed and perfected by actual occupancy within a reasonable time". ${ }^{20}$ It follows that, according to the classical view on occupation that was eventually reached by the end of the nineteenth century, a title is constituted by two essential facts, namely taking territory into possession by an occupying state and establishing some kind of administration thereon. ${ }^{21}$ From a historical perspective there can be

17 Windeyer 1962: 637.

18 "Instructions for Our Trusty George R and well beloved Arthur Phillip Esq. Our Captain General and Governor in Chief, in and over (LS.) Our Territory of New South Wales and its Dependencies, or to the Lieutenant Governor or Commander in Chief of the said Territory for the time being, Given at Our Court at St. James the 25th day of April 1787, in The Twenty Seventh year of Our Reign" (see http://www.austlii.edu.au/cgi-bin/sinodisp/au/other/IndigLRes/1787/ (accessed 10 Jun 2017).

19 Windeyer 1962: 637.

20 Heydte 1935: 460.

21 Oppenheim \& Lauterpacht 1958: 557-558. 
no doubt that British actions initiated in 1788 finally turned out to be a textbook example of creating a title in this particular way. ${ }^{22}$

\section{$4 \quad$ Terra nullius and the question of indigenous inhabitants}

Consideration of the second of the questions raised above requires us to go back to the beginnings of the occupation doctrine. Francisco de Vitoria tells us that occupation as a mode of acquisition known to the law of nature and the law of nations applies only to "deserted land". He does not state expressly that the presence of any indigenous population excludes occupation by European power, yet such a conclusion can be easily derived from the entirety of his work. One of his main theses is that Indians possessed the right to dominium, both in the fields of private and public interests. ${ }^{23}$ Thus, it is clear that at the time of its birth the doctrine of occupation was meant to be applied only to truly no-man's lands, that is territories which were not only under no jurisdiction of a contemporary political entity, but literally uninhabited. Yet, for the centuries to follow that issue remained rather unclear. Vitoria's and many of his successors' position regarding the rights of Indians was determined by their theological and moral background. The Enlightenment changed the intellectual climate in the way that, at least at the first glance, made it even harder to deny the rights of indigenous peoples. In particular, the popular theories of JJ Rousseau boosted the creation of the archetype of a "noble savage", unspoilt by civilisation and thus much closer to the ideas of nature and its law. At this point we move back to Vattel, who managed to deal with this theoretical obstacle in the way that is a sheer mastery of legal gymnastics. Therefore, his reasoning is worth being quoted:

There is another celebrated question, to which the discovery of the new world has principally given rise. It is asked whether a nation may lawfully take possession of some part of a vast country, in which there are none but erratic nations whose scanty population is incapable of occupying the whole? We have already observed ( $\$ 81)$, in establishing the obligation to cultivate the earth, that those nations cannot exclusively appropriate to themselves more land than they have occasion for, or more than they are able to settle and cultivate. Their unsettled habitation in those immense regions cannot be accounted a true and legal possession; and the people of Europe, too closely pent up at home, finding land of which the savages stood in no particular need, and of which they made no actual and constant use, were lawfully entitled

22 A question could arise whether the evident loss of interest in Ausatralia by the Dutch could be considered as abandonment of a land earlier occupied. If the answer was positive, Australia prior to 1788 could rather be defined as terra derelicta. However, as was discussed above, according to the doctrine widely accepted in the times of British colonisation, the Dutch title was only an inchoate one that perished and New Holland definitely remained no-man's land until the establishment of the colony of New South Wales.

Salas 2012: 338 . 
to take possession of it, and settle it with colonies. The earth, as we have already observed, belongs to mankind in general, and was designed to furnish them with subsistence: if each nation had from the beginning resolved to appropriate to itself a vast country, that the people might live only by hunting, fishing, and wild fruits, our globe would not be sufficient to maintain a tenth part of its present inhabitants. We do not therefore deviate from the views of nature in confining the Indians within narrower limits. ${ }^{24}$

And so Vattel did much to convince the European public - and probably himself too - that depriving the beloved "savages" of their territories not only does not violate the law of nature, but is in complete accordance therewith. Obviously, the intricacies and dilemmas of the doctrine of "new worlds" lose all their importance when confronted with the practice of European colonisation. However, it is crucial to realise that this practice did not have much to do with the concept of occupation. As Ruddy aptly summarises, "the history of state practice in this matter indicates that in occupying territory, states did not begin with the classical idea of occupation, but developed into it. European states in establishing dominion over countries inhabited by backward peoples adopted as the method of extension, cession, or conquest, and did not base their rights, in the main, on the occupation of territoria nullius". ${ }^{25}$ Such an observation could be made not only from a historical perspective, since it was rather common when the era of colonisation was at its height. For instance, in 1899 the British author J Macdonell stated that "treaties are concluded with aboriginal races. No nation deems its annexations legitimate without the colour derived from compacts with native chiefs". ${ }^{26}$ However, pre-colonial Australia is underlined by this author as the best example of a "territory sparsely occupied by nomadic tribes possessed of no form of government", ${ }^{27}$ and so as an example of res nullius. It can therefore be regarded as a paradox that a doctrine developed on a Roman basis for the purpose of justifying the claims of European powers to newly discovered territories was rather seldom used in this context. Ruddy's remarks cited above are particularly convincing when we recall the history of the colonial Americas. England, for example, based its claims to the northern continent on discoveries and acts of appropriation taking place since the times of Giovanni Caboto, but the colonisation process performed by both Crown and colonial companies is filled with treaties with native tribes and wars against them. The doctrine of occupation did, of course, find some use in America, especially in the border disputes between colonial powers as an argument in the processes of negotiating the treaties. ${ }^{28}$ Against the background of

24 Vattel 2008: § 209.

25 Ruddy 1968: 278.

26 Macdonell 1899: 285.

27 Idem 284.

28 The Oregon Treaty of 1846 is particularly interesting, because both parties - the UK and the USA - agreed that they had jointly occupied the disputed territory and finally decided to establish a border along the forty ninth parallel. It can therefore be stated that the doctrine of occupation constituted the basis of claims for both powers, but that the eventual titles were also based on the treaty. For further details see Sage 1946. 
the colonisation of Australia - a vast continent acquired by a sovereign power solely on a basis of effective occupation - it seems rather unique, especially in the times when the doctrine of occupation finally took the form we know from the classical law of nations.

Nowadays, the fact that not a single treaty has ever been signed between the European settlers or the Crown and the indigenous peoples of Australia is probably not something to be proud of, ${ }^{29}$ yet it is not the point of this paper to ponder on the mistreatment of indigenous Australians. What should be underlined is the fact that the British colonial authorities never found it useful or advisable to conclude any formal agreement with any of the numerous tribes of Native Australians. This fact makes Australia unique, especially among former British colonies, in not recognising the sovereign ownership of the country by its indigenous population prior to British arrival. ${ }^{30}$ In this connection Australia contrasts most strongly with its close neighbour. The Maori culture, organisation and martial virtues and skills were at such a level that British settlers and the colonial government either had to negotiate with the Maori tribes or declare war against them. New Zealand was consequently founded by the Treaty of Waitangi, ${ }^{31}$ signed by the representatives of the Crown and Maori chiefs, while Australia's beginning shows the factual (even if not exactly conscious) application of the doctrine of occupation combined with a recognition of a whole continent as no-man's land.

It should therefore be emphasised - from the perspective of the creation of sovereignty rights - that the colonisation of Australia provides a rare and probably the only geographically significant example of treating an inhabited land as terra nullius. However, although this matter seems to remain completely clear from the point of view of the general theory of international law, it is being undermined on the ground of Australian common law. Nowadays, some Australian scholars ${ }^{32}$ do so to create a theoretical background for a very late general treaty with the Aborigines and to support their land claims. The courts too, in resolving the issues of such property disputes, tend to deny the "no man's land" internal law doctrine of the past ${ }^{33}$ which was predominant in Australian jurisprudence prior to $1992 .{ }^{34}$ The arguments applied in these discussions relate mainly to common law issues and are therefore of limited importance for problems regarding the law of nations. For instance, the

Williams 2013.

30 Baker et al 1988.

31 See Palmer 2008.

32 Havemann 2005; Williams 2008: 37-48. Some scholars even claim that the doctrine of terra nullius did not exist at the time of arrival of the First Fleet (Connor 2005). Such a thesis may be true in relation to common law, but it cannot withstand a simple confrontation with the main sources of the ius gentium of the seventeenth and eighteenth centuries. Therefore, it is of no importance for the matters discussed in this paper.

33 See Mabo v State of Queensland (No 2) (1992) 107 ALR 1 (Mabo).

34 See supra n $27 \&$ n 28. 
arguments given in the decision of the High Court of Australia in the Mabo case do not contradict the validity of the occupation doctrine in the law of nations. They focus on "the enlarging of the concept of terra nullius by international law to justify the acquisition of inhabited territory by occupation on behalf of the acquiring sovereign raised some difficulties in the expounding of the common law doctrines as to the law to be applied when inhabited territories were acquired by occupation" ${ }^{\prime 35}$ and therefore the formerly recognised absolute ownership title of the Crown is undermined. Moreover, even if we recognise these new arguments and legal facts as convincing even in the field of international law, our present point of view, evidently, cannot change the actual practice of the time of colonisation. This practice was rather clear and indicated a total non-recognition of any sovereignty titles of Aboriginal tribes. It therefore constitutes good factual proof that the thesis of Vattel's somewhat twisted arguments became a part of international law. It can be read in the classic treatises on this discipline that a territory inhabited by natives "under a tribal organization which need not be regarded as a State" can be occupied, ${ }^{36}$ but it is rather clear that such cases were (at least theoretically) rare.

\section{Further applications of the doctrine and its current status}

The uniqueness of the Australian case is clearly visible not only against the background of the history of European colonisation and conquests on other continents, but also in comparison to other examples of usage of the occupation doctrine. As emphasised at the outset of this paper, cases where occupation serves as the sole basis for creation of a title to a territory are generally rare. The list of cases exemplifying the application of the occupation doctrine in the practice of states is very short. Taking all these examples into consideration, the first thing that strikes us is simply the size of Australia in comparison to the surface of such lands as Jan Mayen, Pacific atolls, Bouvet Island or even Svalbard and the eastern coast of Greenland. The last case is particularly interesting as probably the second largest territory ever acquired by means of occupation only. The well-known judgment of the Permanent Court of International Justice, issued in 1933, has had its strong and lasting impact on both international law and geopolitics of the Arctic, but what is most important for the issues contemplated herein is the complete barrenness of the territory considered. Prior to the first attempts of colonisation made by the Danes in the 1920s, the eastern shores of Greenland had been only rarely visited by both Inuit and Europeans, and no permanent settlements had ever existed. ${ }^{37}$ Two main examples of territories appropriated solely by occupation are, therefore, the world's smallest continent and

35 See Mabo sec 34.

36 Oppenheim \& Lauterpacht 1958: 555.

37 For further information on that issue, see Smedal 1931: 77. 
a big portion of the world's largest island, but the crucial difference is that only the former has been inhabited beforehand and was nevertheless considered to be practically terra nullius.

The second half of the nineteenth century brought - as mentioned above - a confirmation of occupation as an institution of customary international law. It even gained some sort of acknowledgement in a treaty, which is in that case the General Act of the Berlin Congo Conference of $1885 .^{38}$ The treaty explicitly provided a possibility of occupation of all portions of Africa's coasts that had not yet been annexed by any of the colonial powers, although it was rather evident that no such lands existed anymore. ${ }^{39}$ The aforementioned atolls on the Pacific Ocean were at that time objects of occupation by both the United Kingdom and the United States and the annexation of the island Jan Mayen - owned by the Dutch in the seventeenth century and abandoned by Norway in 1930 - is usually considered as the last major example of occupation of no-man's (in this particular case - derelict) land. By the 1930s all hospitable or relatively hospitable lands on earth had been acquired by one way or another by sovereign states. If we omit tiny scraps of no-man's land somewhere between usually long-established state borders, only the Antarctic has remained terra nullius until today, and all the declared territorial claims remain "frozen" since the establishment of the Antarctic Treaty System. The last significant territory still unclaimed - Marie Byrd Land - is also subject to Treaty regulations and as such cannot be occupied or claimed. Since the international community has chosen a treaty as a proper way of dealing with the southern circumpolar territories, it is rather unlikely that occupation will ever be considered as a righteous way of gaining sovereignty over any portion of the White Continent. Space law handles the problem of potential territorial acquisitions of celestial bodies even more radically, expressly excluding the possibility of occupation by any state. The prohibition has led scholars to describe the status of sky bodies not with the term of res or terrae nullius, but with other ancient concepts of Roman law: res communis or res extra commercium. ${ }^{40}$ Therefore, the present legal status of the last territories under no sovereignty on earth and all the territories in outer space implies that occupation as a concept is not very likely to be used in any important future case. That certainly gives Australia a substantial chance to remain the most significant case of its application in history.

\section{Conclusion}

The doctrine of occupation, derived from a timeless principle of the Roman law of property, emerged at the dawn of the age of discovery. The sudden appearance of the "new worlds" on the horizon shattered the mentality and consequently many

38 Oppenheim \& Lauterpacht 1958: 559.

39 Koskenniemi 2001: 124.

40 Hara \& Stańczyk 1985: 22. 
legal concepts of the "Old World", and the new idea was meant to respond to these problems. Paradoxically, in most cases it was not sufficient to fit its purpose and was very often supported or replaced by other means of creating sovereignty titles.

Colonisation of Australia coincided with the finalisation of the formation of the classical doctrine of effective occupation. A legal title to the whole continent was created by the British only by taking it into possession as a no-man's land. No treaties were signed with the indigenous peoples of Australia, nor were any regular military operations against them undertaken. The British title has never been contested and no other power has ever tried to establish colonies in Australia. All these facts set aside problems of cession, prescription or conquest as modes of acquiring sovereignty over the Continent. The practice clearly shows that the whole title is based solely on occupation and remains perfectly valid according to classical theories of international law. As was highlighted above, there have not been many cases of acquiring a legal title to territory merely by occupation and almost all of them concern lands that are either small or completely uninhabited. Undoubtedly, Australia stands out among all those examples.

With reference to the beginnings of Australia, it is often highlighted that the idea of such a large penal colony was unique. It is even more worth emphasising that this colonisation was equally uncommon from the perspective of international law. Furthermore, the history of the doctrine of occupation in and of itself provides a strong example of how Roman law was used to form modern legal concepts not only in the field of private law, but international law as well.

\section{BIBLIOGRAPHY}

Baker K et al (1988) “A treaty with the Aborigines?” Policy Issues: 7

Brierly, James Leslie \& Clapham, Andrew (2012) Brierly's Law of Nations. An Introduction to the Role of International Law in International Relations (Oxford)

Connor, Michael (2005) The Invention of Terra Nullius: Historical and Legal Fictions on the Foundation of Australia (Sydney)

Grewe, Wilhelm Georg (2000) The Epochs of International Law (Oxford)

Hara, Ryszard \& Stańczyk, Jerzy (1985) "Space law and Roman law concepts" Postepy Astronautyki 18(3/4): 15-26

Havemann, Paul (2005) "Denial, modernity and exclusion: Indigenous placelessness in Australia" Macquire LJ 4: 57-80

Heydte, Friedrich August von der (1935) "Discovery, symbolic annexation and virtual effectiveness in international law" The American J of International Law 29: 448-471

Holland, Thomas Erskine (1898) Studies in International Law and Diplomacy (Oxford)

Huges, Robert (1987) The Fatal Shore. The Epic of Australia's Founding (New York)

Koskenniemi, Martti (2001) The Gentle Civilizer of Nations. The Rise and Fall of International Law 1870-1960 (Cambridge) 
Lesaffer, Randall (2005) "Argument from Roman law in current international law: Occupation and acquisitive prescription” The European J of International Law16: 25-58

Macdonnel, John (1899) "Occupation and res nullius" J of Society of Comparative Legislation New Series 1: 276-286

Oppenheim, Lassa \& Lauterpacht, Hersch (1958) International Law. A Treatise (Oxford)

Orent, Beatrice \& Reinsch, Pauline (1941) "Sovereignty over islands in the Pacific" The American J of International Law 35: 443-461

Palmer, Matthew SR (2008) The Treaty of Waitangi in New Zealand's Law and Constitution (Wellington)

Ruddy, Francis Stephen (1968) "Res nullius and occupation in Roman and international law" University of Missouri-Kansas City LR 36: 274-287

Sage, Walter N (1946) “The Oregon Treaty of 1846" The Canadian Historical Review 27(4): 349-367

Salas, Victor M (2012) "Francisco de Vitoria on the ius gentium and the American Indios" Ave Maria LR 10: 331-341

Smedal, Gustav (1931) “Acquisition of sovereignty over polar areas"(this text occupies the whole volume of the journal) Skrifter om Svalbard og Oshavet: $36 \mathrm{ff}$

Truyol y Sera, Antonio (1971) "The discovery of the New World and international law" University of Toledo LR 3: 305-321

Vattel, Emerich de (eds B Kapossy \& R Withmore) (2008) The Law of Nations Part I, Chapter XVII, $\S \S 207-208$ available at http://oll.libertyfund.org/titles/2246

Vitoria, Francisco de (1964) De Indis 27 English ed by JB Scott (New York, London)

Williams, George (2013) (accessed 23 Jan 2017) “Treaty with Australia's indigenous people long overdue" Sydney Morning Herald (12 Nov 2013) available at http://www.smh.com.au/ comment/treaty-with-australias-indigenous-people-long-overdue-20131112-2xeel.html

Williams, Kevin (2008) “Critique: A historian said terra nullius was an invention - I'm a blackfella lawyer who has serious concerns about his lack of understanding and knowledge of the common law" The Newcastle LR 10: 37-48

Windeyer, Victor (1962) "The establishment of the Rule of Law in Australia" University of Tasmania LR 1(5): 635-669 